\title{
Enhancement of Educational Internet Use Self-Efficacy Perceptions of Coaching and Recreation Students ${ }^{1}$
}

\author{
Murat Topal $^{2}$
}

\begin{abstract}
Study aimed to investigate the efficiency of the education program that aimed to improve the educational internet use self-efficacy perceptions of coaching and recreation students who were attending formation education at Sakarya University, Faculty of Education. Therefore, a training program designed to develop educational internet use self-efficacy perceptions of students was developed and applied. The study was carried out with 33 students and a total of six weeks of education was given as part of the curriculum prepared for the students. The significant difference between the pre-test and post-test scores of the students was examined by $\mathrm{t}$ test, and the effect size was calculated. According to the findings, there was a significant difference between the educational internet use selfefficacy perceptions of the students between the pre-test and post-test scores in favor of post-test scores. In addition, the opinions of the prospective teachers about the education were taken. It is recommended that similar curriculums should be developed and implemented for Coaching and Recreation student programs.
\end{abstract}

Keywords: Educational internet use self-efficacy perceptions, educational internet use, self-efficacy perceptions, university student, self-efficacy enhancement.

\section{INTRODUCTION}

Instruction of effective use of information and communication technologies is one of the important fields of research for educators today. Rapid developments in technology force similar advances in our approaches to employment, communication, sustaining our lives, education and our needs (WEB1). One of the most significant responsible parties in using information and communication technologies in order to cope with this dynamic structure in our times is the educators. It was observed that certain institutions and organizations around the world have set standards to determine adequate teacher competencies and to develop adequate education programs.

Educational technology standards (WEB2), which include qualifications and skills for students, educators and administrators and developed by the International Society of Technology in Education (ISTE), states that generally students and educators should be individuals who access and question knowledge and actively use technologies in these processes and outside these processes. The horizon report, developed by the New Media Consortium (NMC), focused on drawing up a roadmap for educators and educational politicians by evaluating the future problems and requirements due to

\footnotetext{
1 This study is an extended and improved version of the paper presented at the International Conference on Creative and Innovative Approaches in Education, Science, Arts (ICCIA 2017) congress with the same name.

2 Res. Assist., Sakarya University, Computer Education and Instructional Technologies, mtopal@sakarya.edu.tr
} 
technological advances (WEB3). The digital competencies framework report developed by the European Union for citizens of the European Union stated that contemporary individuals should have information and data literacy, digital age communication and collaboration, digital content production, digital age security and problem-solving skills as a citizenship duty (Carretero, Vuorikari, \& Punie, 2017). One of the important variables for acquisition these skills and competencies is the self-efficacy perceptions of the individuals. Self-efficacy perceptions should be considered in various areas, as well as in the field of information technologies (Akgün, 2008). The development of computer and internet self-efficacy perceptions is directly proportional to the experiences of the individuals (Brinkerhoff, 2006; Compeau \& Higgins, 1995a). Furthermore, studies on internet and computer use indicated that high self-efficacy perceptions affect internet and computer use positively (Durndell \& Haag, 2002).

Self-efficacy perceptions are independent of the individual's ability to conduct a behavior, job or learning task and related to how sufficient the individual considers himself/herself before the action (Bandura, 1997). Therefore, it affects both whether the individual acts or not, the individual's performance during the act, and the outcome of the act (Pajares, 2006). Self-efficacy perceptions have a variable structure and could be increased through various educational processes (Torkzadeh, Pflughoeft \& Hall, 1999). According to Bandura (1986), self-efficacy perceptions develop and increase over time. However, this development is dependent on the increasing maturity of individuals in time and may occur throughout a long period. On the other hand, individuals' low self-efficacy perceptions about a particular case or task may increase with their achievements and positive experiences in the related task (Hill, Smith, \& Mann, 1987; Delcourt \& Kinzie, 1993; Bandura, 1997). The development of self-efficacy perceptions is mainly affected by performance-based activities; in other words, it could be achieved through active direct experiences (Bandura, 1997).

Studies in the literature demonstrated that self-efficacy perceptions could be improved. Schunk (1983) investigated whether awarding the performances and achievements of pre-service teachers had an impact on learning mathematical division skills and improvement of division self-efficacy perceptions. Study findings demonstrated that the students who received performance awards maximized their division skills self-efficacy perceptions in mathematics and these students solved the problems the fastest. In a study conducted by Compeau and Higgins (1995b), they assessed behavior modeling method and conventional instruction method in social cognitive theory based on computer skills and computer self-efficacy perceptions acquired with these two methods. According to the study findings, word processor training instructed with behavior modeling method had no effect on computer selfefficacy perceptions when compared to the conventional method, however the instruction with behavior modeling method in Lotus software training further improved the computer self-efficacy perceptions when compared to the conventional method. Furthermore, self-efficacy perception had a significant impact on computer use performance (Compeau \& Higgins, 1995a, 1995b). In their study, Torkzadeh and Van Dyke (2002) aimed to measure the self-efficacy perceptions of college students on internet use and to improve these self-efficacy perceptions using internet use training. The study demonstrated that the training increased the internet use self-efficacy perceptions of the individuals. Furthermore, individuals with high computer self-efficacy perceptions stated that they were more willing and eager to achieve during the training when compared to other individuals. A study conducted by Salanova, Grau, Cifre, and Llorens (2000) investigated the role of computer self-efficacy in computer use frequency, the level of emotional burnout and computer education. Study findings demonstrated that computer 
training provided for employees who utilize computers in their jobs increased their computer selfefficacy perceptions. Furthermore, the frequency of computer use was found to be directly proportional to computer self-efficacy perceptions.

Although there are several studies in the literature that aimed to determine the level of information technologies self-efficacy perceptions (Akkoyunlu \& Kurbanoğlu, 2003; Akkoyunlu \& Orhan, 2003; Aşkar \& Umay, 2001; Bas, 2011; Çetin, 2008; Eastin \& LaRose, 2000; Eroglu, Unlu, Eroglu, \& Yilmaz, 2011; Gürol \& Aktı, 2010; Koçak Usluel \& Seferoğlu, 2004; Liang \& Tsai, 2008; Tsai \& Tsai, 2003; Tsai \& Tsai, 2005; Tuncer \& Tanaş, 2011; Yenilmez, Turğut, Anapa, \& Ersoy, 2011), there are quite a few empirical studies that aimed to improve information technologies self-efficacy perceptions (Compeau \& Higgins, 1995b; Margolis \& McCabe, 2004; Salanova, Grau, Cifre, \& Llorens, 2000; Torkzadeh \& Van Dyke, 2002). Thus, the present study aimed to investigate the efficiency of the education program that aimed to improve the educational internet use self-efficacy perceptions of coaching and recreation students who were attending formation education at Sakarya University, Faculty of Education.

\section{METHOD}

\section{Research Design}

In order to analyze the development of students' self-efficacy perceptions, single group pretest-posttest model, a quantitative model, was preferred in the study. Study was carried out in the weak experimental design, pretest-posttest single group design. In this design, a single group is studied, and the effect of pretest and posttest, in other words, the dependent variable, was investigated using the same measurement instrument (Büyüköztürk, Kılıç Çakmak, Akgün, Karadeniz, \& Demirel, 2012). Furthermore, the themes and codes for the data collected by obtaining the views of the students before and after the application were identified and the frequencies of these themes and codes are presented.

\section{Study Group}

In the study, purposive sampling method was preferred. Thirty-three students attending Sakarya University, Faculty of Education, Coaching and Recreation Education Department, formation training during the 2016-2017 academic year spring semester participated in the study.

\section{Data Collection Instrument}

"Educational Internet Use Self-Efficacy Beliefs Scale for High School Teachers," developed by Akgün, Topal and Duman (2017) was used as the data collection instrument in the study. The scale is 5-point Likert type scale. The Cronbach alpha internal consistency coefficient calculated by Akgün, Topal and Duman (2017) for the scale was .97. For scale validity, exploratory factor analysis and criterion validity studies were conducted (Akgün, Topal, \& Duman, 2017). The minimum scale score is 26 and the maximum score is 130 points. The scale was applied as pretest and posttest to the students who participated in the training.

Before the application of the pretest, detailed information on the application was provided for the students and they were asked to write down their expectations. After the completion of the training, students were asked to write down their views on the application. These qualitative data were collected with semi-structured forms. 


\section{Implementation of Educational Internet Use Program}

To enhance the educational internet use self-efficacy perceptions of the students, an education that would allow the students to directly develop the related skills was planned, similar the studies by Torkzadeh Van Dyke (2002) and Compeau and Higgins (1995b) that aimed to develop computer selfefficacy perceptions and by Kurbanoğlu and Akkoyunlu (2002) that aimed to develop information literacy self-efficacy perceptions and as reported by Bandura (1997). The program titled "Educational Internet Use," developed by Topal and Akgün (2015) was used after the expectations of the students attending formation training at coaching and recreation department from the course to ensure the suitability of the course for these students and the curriculum target achievements and activities were adapted based on these expectations and the program they were attending. The expectations of the students from the course and the themes and codes obtained from these views are presented in Table 1.

Table 1.

The Expectations of the Students from the Course

\begin{tabular}{|c|c|c|}
\hline & Codes & Frequency \\
\hline 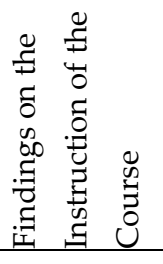 & $\begin{array}{l}\text { The fact that the course was an applied course } \\
\text { Learning and comprehension during the instruction }\end{array}$ & 3 \\
\hline 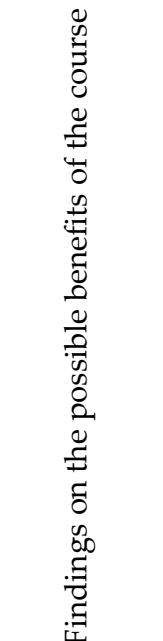 & $\begin{array}{l}\text { Learning how to instruct a fun, active and productive course } \\
\text { How to find material suitable for the instruction pf } \\
\text { psychomotor skills } \\
\text { How to develop material suitable for the instruction pf } \\
\text { psychomotor skills } \\
\text { How to find material suitable for the instruction pf sensory } \\
\text { skills } \\
\text { How to develop suitable for the instruction pf sensory skills } \\
\text { How to develop a simple and comprehensible physical } \\
\text { education course especially for children }\end{array}$ & 4 \\
\hline
\end{tabular}

Student views demonstrated that they expected the course to be more applied and wanted to learn how they could obtain and develop material for the courses they would instruct as teachers or instructors in the future and how to conduct education more effectively. Based on these findings and the programs that the students have attended, an attempt was made to develop a curriculum that would include instructional activities such as face-to-face instruction, finding material on the internet, and access to information/videos on adequate instruction techniques and material for their fields. 
The education program was planned to be conducted in four sessions based on achievements (targets), activities, measurement and evaluation activities, achievement criteria, and location and time. The curriculum was finalized by obtaining the expert views from 1 faculty member with a PhD in program development and two faculty members with a $\mathrm{PhD}$ in education technologies. The course was instructed for six weeks. The program was introduced to the students before the courses. Approximately two weeks after the end of the program, the views of pre-service teachers on the educational program were obtained and the Educational Internet Use Self-Efficacy Beliefs Scale for High School Teachers" was reapplied.

\section{FINDINGS}

Initially, Shapiro-Wilk coefficient is calculated to determine normal distribution of the data, since the sample size was lower than 50 (Can, 2014) in separate groups. Since the Shapiro-Wilk significance values (.196 and .200) for both total pre-test and post-test scale scores were bigger than .05 , it was concluded that the data showed normal distribution. Thus, paired-sample t-test was used to determine whether there was a significant difference between pre-test and post-test scores. The results are presented in Table 2.

Table 2.

Comparison of Pre-test and Post-test Scores of Students' Self-Efficacy Beliefs

\begin{tabular}{llllllll}
\hline & $\mathrm{n}$ & $\bar{X}$ & $\mathrm{ss}$ & $\mathrm{df}$ & $\mathrm{t}$ & $\mathrm{Sig}$ & $\eta^{2}$ \\
\hline Pre-test & 33 & 95.21 & 13.16 & 64 & -2.623 & .011 & 0.009 \\
Post-test & 33 & 104.69 & 16.06 & & & & \\
\hline
\end{tabular}

Analysis of the findings presented in Table 2 demonstrated that there was a significant increase in students' educational internet use self-efficacy belief scores as a result of the education $(t(64)=-2.263, p$ $<.05$ ). The mean pretest score of the students was $\bar{X}=95.21$, and it increased to $\bar{X}=104.69$ after the training. Furthermore, it was found that the calculated effect size was $\eta^{2}=.009$. Since this value was smaller than .06 it can be suggested that the effect size was low (Green and Salkind, 2008). Based on these findings, it was determined that the training significantly increased educational internet use selfefficacy beliefs of the students and was effective; that is, it can be suggested that the developed curriculum was successful.

The themes and codes obtained with the analysis of student views on the conducted training are presented in Table 3. 
Table 3.

Student Views on the Conducted Training

\begin{tabular}{|c|c|c|}
\hline & Codes & Frequency \\
\hline \multirow{3}{*}{ 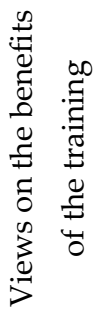 } & The training was useful. & 14 \\
\hline & $\begin{array}{l}\text { The acquired knowledge could be directly used in } \\
\text { professional life. }\end{array}$ & 9 \\
\hline & $\begin{array}{l}\text { This training was more useful when compared to the } \\
\text { previously attended computer courses. }\end{array}$ & 5 \\
\hline \multirow{2}{*}{ 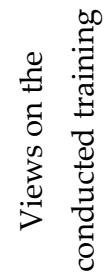 } & $\begin{array}{l}\text { Such a program could be included in coaching/recreation } \\
\text { program curriculum }\end{array}$ & 15 \\
\hline & $\begin{array}{l}\text { I believe that a longer and more comprehensive program } \\
\text { would be more beneficial. }\end{array}$ & 8 \\
\hline
\end{tabular}

Analysis of student views on the training demonstrated that 14 students considered the training useful $(\mathrm{f}=14)$. Nine pre-service teachers stated that they could use the knowledge they acquired in the training directly in their profession. Five students stated that the training was more beneficial when compared to the computer courses they had previously taken in college. The views of the students on the education they attended demonstrated that 15 students preferred the inclusion of such a course in the Coaching and/or Recreation program curriculum, while 8 students stated that the benefits of the program would increase with an increase in the scope and length of the training.

\section{DISCUSSION and CONCLUSION}

The study findings demonstrated that educational internet use self-efficacy perceptions of the students increased statistically at the end of the training program. This finding supported the hypothesis that educational internet use self-efficacy perceptions could be improved by direct experiences (Bandura, 1977; 1997; Compeau \& Higgins, 1995a, 1995b; Pajares, 2006; Salanova, Grau, Cifre, \& Llorens, 2000; Schunk, 1987; Topal \& Akgun, 2015; Torkzadeh, Pflughoeft, \& Hall, 1999; Zimmerman, 1995). Furthermore, the views of the participating students participating on Educational Internet Use Training purposes generally indicated that the education was beneficial. Furthermore, the views of pre-service teachers demonstrated that such a training was beneficial for the vocational and academic lives of coaching and recreation students and they required this type of education. Margolis and McCabe (2004) reported that in order to increase the self-efficacy perceptions of students with low self-efficacy perceptions and resistance to learning, initially, it would be beneficial to support the students to make sufficient efforts, to insist on fulfilling a task, to work hard to cope with the difficulties. Although the duration and scope of the educational Internet Use training conducted in the present study was limited, 
the effectiveness of the training demonstrated that education could improve the educational internet use self-efficacy perceptions of the students. This education program improved the self-efficacy perceptions of students, who were assumed to have low self-efficacy due to the fact that they have never experienced or have never used the activities included in the present study. Thus, the present study findings demonstrated that socio-psychological variables such as self-efficacy perceptions should be considered in the development of information and communication technologies competencies.

\section{REFERENCES}

Akgün, Ö. E., Topal, M., \& Duman, İ. (2017). Lise öğretmenlerine yönelik eğitim amaçlı internet kullanımı öz-yeterlik inançları ölçeğinin geçerlik ve güvenirlik çalışması. Medeniyet Eğitim Araştırmaları Dergisi, 1(2), 1-14.

Akkoyunlu, B., \& Kurbanoğlu, S. (2003). Öğretmen adaylarının bilgi okuryazarlığı ve bilgisayar öz yeterlik algıları üzerine bir çalışma. Hacettepe Üniversitesi Ĕ̆itim Fakültesi Dergisi, 24(1), 1-10.

Akkoyunlu, B., \& Orhan, F. (2003). Bilgisayar ve öğretim teknolojileri eğitimi (BÖTE) bölümü öğretmen adaylarının bilgisayar kullanma öz-yeterlik inancı ile demografik özellikleri arasındaki ilişki. The Turkish Online Journal of Educational Technology, 2(3), 86-93.

Aşkar, P., \& Umay, A. (2001). İlköğretim matematik öğretmenliği öğretmen adaylarının bilgisayarla ilgili öz-yeterlik inançları. Hacettepe Üniversitesi Eğitim Fakültesi Dergisi, 21, 1-8.

Akgün, Ö. E. (2008). Bilgisayar öz-yeterlik algısı. D. Deryakulu (Eds.), Bilişim teknolojileri eğitiminde sosyopsikolojik değişkenler (1-32). Ankara: Maya Akademi.

Bandura, A. (1977). Self-efficacy: Toward a unifying theory of behavioral change. Psychological Review, 84(2), 191.

Bandura, A. (1986). Social foundations of thought and action: A social cognitive theory. Prentice-Hall, Inc.

Bandura, A. (1997). Self-efficacy: The exercise of control. New York: Freeman.

Bandura, A., \& Schunk, D. H. (1981). Cultivating competence, self-efficacy, and intrinsic interest through proximal self-motivation. Journal of Personality and Social Psychology, 41(3), 586.

Baş, G. (2011). İlköğretim öğretmenlerinin eğitsel internet kullanımı öz-yeterlik inançlarının farklı değişkenler açısından incelenmesi. Eğitim Teknolojisi Kuram ve Uygulama, 1(2), 35-51.

Brinkerhoff, J. D. (2006). Effects of a long-duration, professional development academy on technology skills, computer self-efficacy, and technology integration beliefs and practices. Journal of Research on Technology in Education, 39(1), 22-43.

Büyüköztürk, Ş., Kılıç Çakmak, E., Akgün, Ö. E., Karadeniz, Ş., \& Demirel, F. (2012). Bilimsel araştırma yöntemleri (11. Bask1). Ankara: PegemA Yayıncıllk.

Carretero, S., Vuorikari, R., \& Punie, Y. (2017). DigComp 2.1: The digital competence framework for citizens. Publications Office of the European Union, Luxembourg. 
Compeau, D. R., \& Higgins, C. A. (1995a). Computer self-efficacy: Development of a measure and initial test. MIS quarterly, 19(2), 189-211.

Compeau, D. R., \& Higgins, C. A. (1995b). Application of social cognitive theory to training for computer skills. Information Systems Research, 6(2), 118-143.

Compeau, D. R., Higgins, C.A., \& Huff, S. (1999). Social cognitive theory and individual reactions to computing technology: A longitudinal study. MIS quarterly, 23(2), 145-158.

Creswell, J. W., \& Plano Clark, V.L. (2011). Designing and conducting mixed methods research. Second edition. California: Sage Publications.

Çoklar, A. N., \& Odabaşı, H. F. (2009). Educational Technology Standards Scale (ETSS): A study of reliability and validity for Turkish preservice teachers. Journal of Computing in Teacher Education, 25(4), 135-142.

Demiralay, R., \& Karadeniz, Ş. (2010). Bilgi ve iletişim teknolojileri kullanımının, ilköğretim öğretmen adaylarının bilgi okuryazarlığı öz-yeterlik algılarına etkisi. Kuram ve Uygulamada Ĕ̆itim Bilimleri (KUYEB), 10(2), 819-851.

Delcourt, M. A. B., \& Kinzie, M. B. (1993). Computer technologies in teacher education: The easurement attitudes and self-efficacy. Journal Research and Development in Education, 27(1), 35-41.

Durndell, A., \& Haag, Z. (2002). Computer self efficacy, computer anxiety, attitudes towards the internet and reported experience with the internet, by gender, in an east european sample. Computers in Human Behavior, 18(5), 521-535.

Eastin, M. S., \& LaRose, R. (2000). Internet self-efficacy and the psychology of the digital divide. Journal of Computer Mediated Communication, 6(1). Retrieved from http://jcmc.indiana.edu/vol6/issue1/eastin.html.

Eroğlu, A., Ünlü, H., Eroğlu, İ., \& Yılmaz, B. (2011). Beden eğitimi öğretmeni ve beden eğitimi öğretmen adaylarının eğitsel internet kullanımına yönelik yeterliklerinin incelenmesi. Selçuk Üniversitesi Beden Ĕgitim ve Spor Bilimleri Dergisi, 13(1), 132-135.

Gürol, A., \& Aktı, S. (2010). The relationship between pre-service teachers' self efficacy and their internet self efficacy. Procedia Social and Behavioral Sciences, 2(2), 3252-3257.

Green, S. B., \& Salkind, N. J. (2008). Using SPSS for windows and macintosh: Analyzing and understanding data. Upper Saddle River: Pearson; Prentice Hall.

Hill, T., Smith, N. D., \& Mann, M. F. (1987). Role of efficacy expectations in predicting the decision to use advanced technologies: The case of computers. Journal of Applied Psychology, 72(2), 307.

ISTE, (2008). National educational standards for teachers. Retrieved from http://www.iste.org/docs/pdfs/nets-t-standards.pdf?sfvrsn=2 .

Kayaduman, H., Sarıkaya, M., \& Seferoğlu, S. S. (2011). Eğitimde FATİH projesinin öğretmenlerin yeterlik durumları açısından incelenmesi. Akademik Bilişim Konferansı, 2-4 February / İnönü University, Malatya. Retrieved from www.ab.org.tr/ab11/bildiri/136.doc . 
Kirschner, P., \& Woperies, I. G. J. H. (2003). Mind tools for teacher communities: A European perspective. Technology, Pedagogy, and Education, 12(1), 127-149.

Koçak Usluel, Y., \& Seferoğlu, S. S. (2004). Öğretim elemanlarının bilgi teknolojilerini kullanmada karşılaştıkları engeller, çözüm önerileri ve öz-yeterlik algıları. Eğitim Bilimleri ve Uygulama, 6(3), 143-157.

Kurbanoğlu, S., \& Akkoyunlu, B. (2002). Öğretmen adaylarına uygulanan bilgi okuryazarlığ1 programının etkililiği ve bilgi okuryazarlığı becerileri ile bilgisayar öz-yeterlik algısı arasındaki ilişki. Hacettepe Üniversitesi Ĕ̆itim Fakültesi Dergisi, 22, 98-105.

Liang, J. C., \& Tsai, C. C. (2008). Internet self-efficacy and preferences toward constructivist internet based learning environments: A study of pre-school teachers in Taiwan. Educational Technology and Society, 11(1), 226-237.

Margolis, H., \& McCabe, P. P. (2004). Self-efficacy a key to improving the motivation of struggling learners. The Clearing House, 77(6), 241-250.

MEB, (2013). Milli Ĕğitim Bakanlığı öğretmen yeterlikleri. Retrieved from http://otmg.meb.gov.tr/YetGenel.html .

National Science Foundation. (2010). A Roadmap for educational technology. Retrieved from http://www.cra.org/ccc/files/docs/groe/Roadmap\%20for\%20Education\%20 Technology\%20\%20Summary\%20Brochure.pdf .

New Media Consortium. (2014). The 2014 horizon report. Austin, Texas: The New Media Consortium. Retrieved from http://www.nmc.org/pdf/2014-nmc-horizon-report-he-EN.pdf.

Özçelik, H., \& Kurt, A. A. (2007). İlköğretim öğretmenlerinin bilgisayar özyeterlikleri: Balıkesir ili örneği. İlköğretim Online, 6(3), 441-451.

Pajares, F. (2006). Self-efficacy during childhood and adolescence. F. Pajares \& T. Urdan (Eds.), Selfefficacy beliefs of adolescents (339-367). Greenwich, CT: Information Age Publishing.

Salanova, M., Grau, R. M., Cifre, E., \& Llorens, S. (2000). Computer training, frequency of usage and burnout: The moderating role of computer self-efficacy. Computers in Human Behavior, 16(6), 575-590.

Sam, H. K., Othman, A. E. A., \& Nordin, Z. S. (2005). Computer self-efficacy, computer anxiety, and attitudes toward the internet: A study among undergraduates in unimas. Educational Technology \& Society, 8(4), 205-219.

Schunk, D. H. (1981). Modelling and attributional effects on children's achievement: A self-efficacy analysis. Journal of Educational Psychology, 74, 93-105.

Schunk, D. H. (1983). Ability versus effort attributional feedback: Differential effects on self-efficacy and achievement. Journal of Educational Psychology, 75, 848-856.

Schunk, D. H. (1984). Enhancing self-efficacy and achievement through rewards and goals: Motivational and informational effects. The Journal of Educational Research, 78(1), 29-34.

Schunk, D. H. (1985). Self-efficacy and classroom learning. Psychology in the Schools, 22(2), 208-223. 
Schunk, D. H. (1987). Peer models and children's behavioral change. Review of Educational Research, 57, 149-174.

Schunk, D. H. (2009). Öğrenme teorileri: Eğitimsel bir bakış. Ankara: Nobel Yayın Dağıtım. (Originally Published 1991).

Seferoğlu, S., \& Akbıyık, C. (2005). İlköğretim öğretmenlerinin bilgisayara yönelik öz-yeterlik algıları üzerine bir çalışma. Eğitim Araştırmaları Dergisi, 19, 89-101.

Stellar Project. (2014). http://www.stellarproject.eu/

Şahin, İ. (2009). Eğitsel İnternet Kullanım Özyeterliği İnançları Ölçeğinin geçerliği ve güvenirliği. Selçuk Üniversitesi Sosyal Bilimler Enstitüsü Dergisi, 21, 461-471.

Topal, M. (2013). Eğitim fakültesinde okuyan öğretmen adaylarının eğitim amaçlı internet kullanımı öz-yeterlik algilarının incelenmesi ve geliştirilmesi (Yayımlanmamış yüksek lisans tezi). Sakarya Üniversitesi Eğitim Bilimleri Enstitüsü, Sakarya.

Topal, M., \& Akgün, Ö. (2015). Eğitim fakültesi son sınıf öğrencileri için hazırlanan eğitim amaçlı internet kullanımı öz-yeterliğini geliştirme programının etkililiği. İlköğretim Online, 14(2), 697712 .

Torkzadeh, R., Pflughoeft, K., \& Hall, L. (1999). Computer self-efficacy, training effectiveness and user attitudes: An empirical study. Behaviour \& Information Technology, 18(4), 299-309.

Torkzadeh, G., \& Van Dyke, T. P. (2002). Effects of training on internet self-efficacy and computer user attitudes. Computers in Human Behavior, 18(5), 479-494.

Tsai, M. J., \& Tsai, C. C. (2003). Information searching strategies in web-based science learning: The role of internet self-efficacy. Innovations in Education and Teaching International, 40(1), 43-50.

Tuncer, M., \& Aytaç, Ö. (2012). Sınıf öğretmeni adaylarının eğitsel internet kullanımına yönelik özyeterlik inançları. International Periodical tor the Languages, Literature and History of Turkish or Turkic, 7(2), 1079-1091.

Yaman, S., \& Yalçın, N. (2005). Fen eğitiminde probleme dayalı öğrenme yaklaşımının problem çözme ve öz-yeterlik inanç düzeylerinin gelişimine etkisi. Hacettepe Üniversitesi Ĕ̆itim Fakültesi Dergisi, 29, 229-236.

Yenilmez, K., Turğut, M., Anapa, P., \& Ersoy, M. (2011). İlköğretim matematik öğretmeni adaylarının eğitsel internet kullanımına yönelik öz-yeterlik inançları. 5th International Computer \& Instructional Technologies Symposium,, Elazığ-Turkey: Fırat University.

Zimmerman, B. J. (1995). Self-efficacy and educational development. A. Bandura (Ed.), Self-Efficacy in changing societies (s. 202-231). New York: Cambridge University Press.

WEB1, International Society for Technology in Education (ISTE), standarts for educators, https://www.iste.org/standards/for-educators.

WEB2, International Society for Technology in Education (ISTE), https://www.iste.org/standarts

WEB3, New Media Consortium, The Horizon Report, https://www.nmc.org/nmc-horizon/ 